\title{
La política de Estado como elemento de los crímenes internacionales
}

\author{
WILLIAM A. SCHABAS*
}

\begin{abstract}
SUMARIO: I. EL DEBATE Y LAS AUTORIDADES.- II. GENOCIDIO: ¿INTENCIÓN ESPECÍFICA, O PLAN O POLIITICA?- III. LIMITANDO LA RESPONSABILIDAD DEL ESTADO Y LA RESPONSABILIDAD PENAL INDIVIDUAL.- IV. ESTADO O POLÍTICA «ORGANIZACIONAL».- V. EMPRESA CRIMINAL CONJUNTA, "CRÍMENES DE LARGA ESCALA» Y PLAN O POLÍTICA DE ESTADO.- VI. GRAVEDAD.
\end{abstract}

\section{NTRODUCCIÓN}

«Los crímenes contra el Derecho internacional son cometidos por personas, no por entidades abstractas, y solamente pueden hacerse cumplir las disposiciones del Derecho internacional cuando se castiga a las personas que cometieron estos crímenes», afirma una sentencia del Tribunal Militar Internacional ${ }^{1}$. Esta frase, frecuentemente citada, expresa una idea primordial, pero puede también haber contribuido a algunas ideas equivocadas acerca de la naturaleza de los crímenes internacionales. El Tribunal de Nuremberg realizó esta declaración en respuesta a la afirmación de que los líderes nazis no eran responsables porque actuaron en interés del Estado. La famosa declaración de «entidades abstractas» puede inducir al engaño al sugerir que el papel del Estado es irrelevante o incluso secundario cuando se habla de crímenes contra el Derecho internacional.

El artículo VI del Estatuto del Tribunal Militar Internacional definió la jurisdicción material de la corte. Los principales delitos aparecen incluidos en tres diferentes párrafos: son crímenes contra la paz, crímenes de guerra y crímenes contra la humanidad. También aquí, con frecuencia, se ha ignorado un elemento importante. El artículo VI comienza con un párrafo introductorio en el que se menciona que los criminales deben haber «actuado en interés de los países del Eje Europeo» ${ }^{2}$. Esto introduce una atingencia en la frase «los crímenes contra el Derecho internacional son cometidos por personas», en la medida que «las personas» deben actuar en beneficio de un Estado. Incluso la lectura detenida del resumen de la sentencia, emitida el 30 de septiembre y el primero de

\footnotetext{
* Oficial delaOrden de Canadá(OC), miembrodelaReal Academia delrlanda(MRIA), catedráticodeDerecho de los Derechos Humanos en la Universidad Nacional de Irlanda, Galway; director del Centro Irlandés de Derechos Humanos, Global Legal Scholar, en la Universidad de Warwick, Facultad de Derecho; profesor visitante de la Facultad de Derecho de la Universidad Queen, de Belfast, y de la Universidad LUISS Guido Carli, de Roma (2008).

1 Francia et al. v. Goering et al., (1946) 22 IMT 203; 13 ILR 203; 41 American Journal of International Law 172 , p. $221(A J I L)$.

2 AcuerdoparaJuzgary CastigarlosPrincipales CriminalesdeGuerradelEjeEuropeoyEstablecerelEstatuto del Tribunal Militar Internacional (TMI), anexo (1951) 82 UNTS 279, artículo VI.
} 
octubre de 1946, clarifica la relevancia que tuvo para la fiscalía el plan o la política del Estado nazi.

Sin embargo, desde hace unos años, la jurisprudencia ha tendido a restar importancia al papel de un plan o política de Estado en los crímenes internacionales. En la primera acusación de genocidio conocida por el Tribunal Penal Internacional para la Antigua Yugoslavia, la Sala de Primera Instancia afirmó que un plan o política de Estado no era un elemento del crimen de genocidio y que el delito podía ser cometido por un individuo actuando solo, sin participación alguna del Estado ${ }^{3}$. Unos años después, la Sala de Apelaciones del Tribunal llegó prácticamente a la misma conclusión con relación a los crímenes contra la humanidad ${ }^{4}$. Subyacente a este desarrollo del Derecho, puede existir preocupación en cuanto a que requerir un plan o política de Estado como elemento de dichos crímenes dificultará el juicio de los llamados «actores no estatales».

No obstante, en la práctica, ha habido pocos o ningún caso ante tribunales internacionales que involucren a villanos emprendedores que hayan explotado una situación de conflicto para sacar adelante sus propias y perversas agendas personales. En esencia, todos los procesos han involucrado criminales que han actuado en nombre del Estado y según su política, o los que actuaban en nombre de una organización parecida a un Estado, como la Republika Srpska, en la medida en que estaba intentando controlar el territorio y hacerse del poder político. De hecho, en 2005, una comisión experta de investigación, a la cual el Consejo de Seguridad ordenó investigar si estaba cometiéndose un genocidio en Darfur, respondió la pregunta concluyendo que «el Gobierno de Sudán no ha seguido una política de genocidio ${ }^{5}$.

Otros factores dentro de la dinámica disciplina del Derecho penal internacional argumentan en favor de la recuperación del papel del plan o de la política de Estado como elemento de los crímenes internacionales. El Estatuto de Roma de la Corte Penal Internacional y los Elementos de los Crímenes, que complementan su interpretación, sugieren un papel en cierta forma realzado para la política de Estado, al compararlo con el que ocupa en la jurisprudencia de los tribunales ad hoc. Además, con la creciente atención en la «gravedad» como prueba para distinguir los casos que merecen la atención de los tribunales internacionales, el requisito de un plan o política de Estado puede ser útil para su determinación.

Cuando la importante doctrina de la «empresa criminal conjunta» se aplica a los llamados «grandes casos», el elemento del plan o política del Estado es decisivo. «Empresa criminal conjunta» es la expresión empleada en el Derecho penal internacional para describir lo que dentro de los

3 Fiscalía v. Jelisić (caso N IT-95-10-T), sentencia, 14 de diciembre de 1999, párrafo 100. Confirmado en la apelación: Fiscalía v. Jelisić (caso N ${ }^{\circ}$ IT-95-10-A), sentencia, 5 de julio de 2001, párrafo 48.

4 Fiscalía v. Kunarac et al. (caso $\mathrm{N}^{\circ}$ IT-96-23/1-A), sentencia, 12 de junio de 2002, párrafo 98.

5 InformedelaComisiónInternacionaldelnvestigacionesdeViolacionesdelDerecholnternacionalHumanitario y de los Derechos Humanos en Darfur, documento de las Naciones Unidas, S/2005/60, párrafo 518. 
sistemas penales nacionales se conoce como «asociación para delinquir». Quizá de mayor interés, el requisito de plan o política de Estado para ciertos crímenes internacionales, sobre todo el genocidio y los crímenes de lesa humanidad, facilita conjugar la perspectiva de la responsabilidad penal individual con la responsabilidad del Estado.

\section{EL DEBATE Y LAS AUTORIDADES}

La Oficina del Fiscal del Tribunal Penal Internacional para la Antigua Yugoslavia tuvo mucha precaución para emitir acusaciones de genocidio con relación a las atrocidades que se cometieron durante la guerra en Bosnia-Herzegovina, de 1992 a 1995. De hecho, parece que hubo una gran diferencia de opinión sobre la materia dentro de la propia oficina, en torno a si genocidio era el término legal apropiado para describir las atrocidades que se describieron de manera amplia como «limpieza étnica» ${ }^{6}$. Sin embargo, unas cuantas acusaciones incluyeron cargos de genocidio y una de ellas fue llevada ante los tribunales en 1999. Involucró a un severamente perturbado racista serbio, quien fue el principal verdugo en el campo de Luka, al noroeste de Bosnia, durante dos semanas. Se demostró que asesinó de manera sistemática a presos musulmanes, además de algunos croatas. Entre las víctimas se encontraban prácticamente todos los líderes de la comunidad musulmana. Jelisić fue acusado de genocidio, además de crímenes de lesa humanidad, en calidad de cómplice y autor principal. Aceptó declararse culpable de los crímenes de lesa humanidad. Sin embargo, el fiscal no quedó satisfecho e insistió en que el juicio se llevara a cabo por el cargo de genocidio.

Al examinar con detenimiento las pruebas del caso de la fiscalía, la Sala de Primera Instancia, presidida por el juez Claude Jorda, concluyó que no se había demostrado la existencia de ningún plan o política organizada de un Estado o entidad similar para asesinar total o parcialmente a los musulmanes bosnios. Por lo tanto, la Sala de Primera Instancia señaló que Jelisić no pudo ser en absoluto cómplice de genocidio porque el genocidio nunca fue cometido por otros. Es decir, no había suficiente evidencia de que se hubiera perpetrado genocidio en Bosnia, en el sentido de que hubiera habido algún tipo de ataque organizado o planeado contra la población musulmana, de acuerdo con la Sala de Apelaciones? Pero después de retirar el cargo de complicidad en el genocidio, esta pasó a analizar si Jelisić había cometido o no genocidio al haber actuado solo como principal autor del crimen, en lugar de como cómplice. La Sala de Primera Instancia afirmó que era «teóricamente posible» que un individuo en concreto, actuando solo, pudiera cometer el crimen -una especie de Lee Harvey Oswald del genocidio-. Finalmente, Jelisić fue también absuelto como autor principal del crimen. Sin embargo, la Sala de Primera Instancia adoptó un enfoque de obiter dictum, de una forma 
más apropiada para la psiquiatría que para el Derecho penal, el cual es ahora la referencia para la suposición hipotética y especulativa de que puede cometerse genocidio sin que se requiera plan o política organizada alguna por un Estado o entidad parecida ${ }^{8}$. La posición de la Sala de Primera Instancia fue ratificada durante la apelación.

La Sala de Apelaciones considera que la existencia de un plan o política no es un elemento legal del crimen. Sin embargo, en el contexto de demostrar intención específica, la existencia de un plan o política puede convertirse en un factor de importancia en la mayoría de casos. Las pruebas pueden ser consistentes con la existencia de un plan o política, o incluso demostrar dicha existencia, y, a su vez, la existencia de un plan o política puede facilitar la existencia de un crimen?

No obstante, estas opiniones no han demostrado tener importancia alguna en los siguientes juicios por genocidio en el Tribunal Penal Internacional para la Antigua Yugoslavia. Por ejemplo, a pesar de que en dos casos el Tribunal llegó a la conclusión de que hubo genocidio, no se produjo condena alguna. La principal preocupación aquí radica en que en ninguno de los casos se debatió si los individuos, actuando de forma aislada, pueden cometer genocidio. En relación con el primer caso, el general Krstić, después de ser condenado en un primer momento por genocidio por la Sala de Primera Instancia ${ }^{10}$, fue absuelto del cargo por la Sala de Apelaciones, aunque declarado culpable de cooperación delictiva del genocidio perpetrado en Srebenica, en 1995, bajo las órdenes del general Ratko Mladić ${ }^{11}$. El coronel Blagojević, otro subordinado de Mladić, también fue condenado por genocidio por la Sala de Primera Instancia ${ }^{12}$, pero el fallo fue revocado en apelación ${ }^{13}$.

En el caso Krstić, se aborda el desarrollo de los hechos en el encabezado «Plan para ejecutar a los musulmanes bosnios de Srebrenica». Esta ciudad está ubicada en el este de Bosnia y tuvo una gran importancia estratégica para los serbio-bosnios. Estos requerían eliminar a la población musulmana de la zona para así unir dos grandes áreas que contaban con mayoría serbia. A lo largo de pocos días de mediados de julio de 1995, unidades militares serbias ejecutaron sumariamente a siete mil hombres musulmanes, incluyendo jóvenes adolescentes. La Sala de Primera Instancia concluyó que, tras la toma de Srebrenica en julio de 1995, los serbio-bosnios idearon e implementaron un plan para ejecutar cuantos musulmanes bosnios en edad militar hubiera en dicho lugar ${ }^{14}$. El tema central, en términos de la culpabilidad del general Krstić, era si él tenía

8 Ibid., párrafo 100.

9 Fiscalía v. Jelisić (caso N IT-95-10-A), sentencia, 5 de julio de 2001, párrafo 48 (el énfasis es nuestro). EI obiterdictum de la Sala de Apelaciones fue seguido en Fiscalía v. Sikirica etal.(caso $\mathrm{N}^{\circ}$ IT-95-8-T), sentencia sobre la petición de defensa de absolver, 3 de septiembre de 2001, párrafo 62 .

10 Fiscalia v. Krstić (caso $\mathrm{N}^{\circ}$ IT-98-33-T), sentencia, 2 de agosto de 2001.

11 lbid., 19 de abril de 2004.

12 Fiscalia v. Blagojević et al. (IT-02-60-T), sentencia, 17 de enero de 2005.

13 Fiscalia v. Blagojević et al. (IT-02-60-A), sentencia, 9 de mayo de 2007.

14 Fiscalia v. Krstić (caso $N^{\circ}$ IT-98-33-T), sentencia, 2 de agosto de 2001, párrafo 87. También en ibid., párrafo 427. 
conocimiento o no del plan. Las conclusiones de la Sala de Primera Instancia fueron las siguientes: «Puede que no hubiera ideado el plan para ejecutar bosnios, pero dicho plan se llevó a cabo dentro de la zona de responsabilidad del Drina Corps. Además, se utilizaron los recursos del Drina Corps para ayudar en las ejecuciones a partir del 14 de julio de 1995 y en adelante. En virtud de su posición de Comandante de Drina Corps desde el 13 de julio de 1995, el general Krstić debía estar informado de los hechos» ${ }^{15}$.

A pesar de reconocer el fallo de la Sala de Apelaciones en el caso Jelisić, en cuanto a que un plan no era un elemento requerido en el crimen de genocidio, la Sala de Primera Instancia no consideró que esto fuera importante, al tener en cuenta su propia conclusión, que señaló que los asesinatos fueron en realidad planeados ${ }^{16}$. En Blagojević, el otro caso de Srebrenica en el que se emitió sentencia, la Sala de Apelaciones revocó una condena por complicidad para cometer genocidio esencialmente porque el acusado desconocía las ejecuciones en masa y, por lo tanto, no podría haber conocido el plan $^{17}$.

De tal modo, hasta la fecha, los juicios de Srebrenica no han incluido debate alguno acerca de si, actuando aisladamente, personas pueden cometer genocidio porque las Salas de Primera Instancia y la Sala de Apelaciones han llegado a la conclusión de que las matanzas masivas de hombres bosnios formaron parte de un «plan de ejecución» ordenado por un Estado o entidad cuasi estatal. Todos los otros juicios por genocidio en el Tribunal Penal Internacional para la Antigua Yugoslavia han resultado en absoluciones o retiro del cargo de genocidio. En el Tribunal Penal Internacional para Ruanda, el tema ni siquiera ha surgido. Todos los observadores conocedores de la materia comprenden que el genocidio ruandés involucró indiscutiblemente un plan o política que provenía del Estado o, como mínimo, de una poderosa camarilla suya.

Sin embargo, las pruebas de los casos de Srebrenica también demuestran que el «plan de ejecución» fue una empresa improvisada y de último minuto, diseñada por el general Mladić y sus colaboradores más cercanos alrededor del 11 y 12 de julio de 1995. De acuerdo con ello, el fiscal no intentó establecer de manera seria la existencia de un plan anterior a esa fecha, el cual que habría formado parte de una estrategia general de genocidio del liderazgo serbio-bosnio ${ }^{18}$. Por lo tanto, en los juicios de Srebrenica, la evidencia no ha intentado sugerir un plan genocida más allá de la visión del liderazgo militar local. Ninguna de la información del juicio de Milošević o de los procesos llevados ante la Corte Internacional de Justicia, en la solicitud por parte Bosnia y Herzegovina contra Serbia y Montenegro, apunta a que la masacre de Srebrenica 
fue organizada, planeada y coordinada, en su denominada «dimensión genocida», en un nivel superior, o que respondió a las órdenes de un plan estratégico. Más bien, se ha presentado como una variante local perversa de una campaña de limpieza étnica de serbios. Pero en general, el programa de limpieza étnica no ha sido reconocido por las autoridades judiciales como genocida, hecho que ha sido confirmado por la sentencia de la Corte Internacional de Justicia ${ }^{19}$. En consecuencia, establecer que la masacre de Srebrenica fue organizada a nivel local y que no fue simplemente un acto aleatorio no responde necesariamente a que el genocidio deba ser cometido según un plan o política de Estado. Si se impone este criterio, obligaría a una revisión de la naturaleza genocida de los crímenes cometidos en Srebrenica en julio de 1995.

Desafortunadamente, la Sala de Apelaciones del Tribunal Penal Internacional para la Antigua Yugoslavia amplió su enfoque acerca de la materia del plan o política de Estado - principalmente, que la existencia de un plan o política no es un elemento legal del crimen - de genocidio para abarcar crímenes contra la humanidad. De hecho, en el fallo se refirió al caso Jelisić para respaldarlo ${ }^{20}$. Durante este último, el Tribunal se había apoyado en la lectura literal de la definición del crimen. En efecto, el texto de la definición no contiene el requisito explícito de un plan o política. De forma similar y con respecto a los crímenes de lesa humanidad, el texto del estatuto no contiene requisito explícito de plan o política. Por otro lado, la Sala de Apelaciones reconoció que existía gran debate en torno a la cuestión en la jurisprudencia y de la doctrina. No obstante, por increíble que parezca, el debate en torno a este punto tan importante quedó relegado a una nota a pie de página acerca de la sentencia de la Sala de Apelaciones ${ }^{21}$. Cuando se examina a los

19 CasorelacionadoconlaAplicación delaConvenciónsobrelaPrevenciónyCastigodelCrimendeGenocidio (Bosnia and Herzegovina v. Serbia and Montenegro), sentencia, 26 febrero de 2007.

20 Fiscalía v. Kunarac et al. (caso $N^{\circ}$ IT-96-23 y IT-96-23/1-A), sentencia, 12 de junio de 2002, fn. 114.

$21 \mathrm{lbid}$ : «Sehadebatido, dentrodelajurisprudencia deeste Tribunal, siuna política o plan representan indicio paradefinircrímenesdelesahumanidad.LoscasosestudiadosporlaSaladeApelacionesapoyademanera abrumadoraelargumentodequetalesrequisitosnoexistenbajoelderechointernacionalconsuetudinario". Véase, por ejemplo, el artículo 6(c) del Estatuto de Nuremberg; sentencia de Nuremberg, Juicio de los Principales Criminales deGuerraanteelTribunal MilitarInternacional,Nüremberg,14denoviembrede 1945primero de octubre de 1945, en particular las páginas 84, 254, 304 (Streicher) y 318-319 (von Schirach); artículo II(1)(c) de la Ley del Consejo de Control $N^{\circ}$ 10; In re Ahlbrecht, ILR 16/1949, 396; Ivan Timofeyevich Polyukhovich v. La Commonwealth de Australia y Anor, (1991) 172 CLR 501; caso FC 91/026; Fiscanl Generall v. Adolph Eichmann, Tribunal de Distrito de Jerusalén, caso penal $N^{\circ} 40 / 61$; Mugesera et al. v. Ministro de Ciudadanía e Inmigración, IMM-5946-98, 10 de mayo de 2001, Corte Federal de Canadá, Sala de PrimeraInstancia In re Trajkovic, Tribunal de Distrito de Gjilan (Kosovo, República Federal de Yugoslavia), P Nr 68/2000, 6 de marzo de 2001; Moreno v. Canada (Ministro de Trabajo e Inmigración), Corte Federal de Canadá, Corte de Apelaciones, ?1994g 1 F.C. 298, 14 de septiembre de 1993; Sivakumar v. Canadá (Ministro de Trabajo e Inmigración), Corte Federal de Canadá, Corte de Apelaciones, ?1994g 1 F.C. 433, 4 de noviembre de 1993. Véase el Informe del Secretario General según párrafo 2 de la Resolución del Consejo de Seguridad 808(1993), S/25704, 3 de mayo de 1993, párrafos 47-48; Anuario de la Comisión de Derecho Internacional (ILC), 1954, volumen II, 150; Informe de la CDI sobre el trabajo de su $43^{\circ}$ período de sesiones, 29 abril-19 de julio de 1991, Suplemento $N^{\circ} 10$ ( Documento de las Naciones Unidas, $N^{\circ} A / 46 / 10$ ), 265-266; $46^{\circ}$ período de sesiones, 2 de mayo-22 de julio de 1994, Suplemento $\mathrm{N}^{\circ} 10$ (Documento de las Naciones Unidas, $\mathrm{N}^{\circ} \mathrm{A} / 49 / 10$ ), 75-76; $47^{\circ}$ período de sesiones, 2 de mayo-21 de julio de 1995, 47, 49 y 50; $48^{\circ}$ período de sesiones, 6 de mayo-26 de julio de 1996, Suplemento $N^{\circ} 10$ (Documento de las Naciones Unidas, A/51/10), 93 y 95-96. La Sala de Apelaciones llegó a la misma conclusión con relación al crimen de genocidio (Sentencia de Apelación de Jelisic, párrafo 48). Algunas de las decisiones que sugieren que se requiere un plan o política fueron, en ese sentido, más allá del texto delestatuto que debía aplicarse (véase, por ejemplo, Fiscalía Pública v. Menten, Corte Superior de Holanda, 13 de enero de 1981, reimpreso en 75 ILR331,362-363). Otras referencias con relación a un plan opolítica que se han usadoa veces para sostener 
legisladores mencionados en la referencia, no queda claro en absoluto cuántos de ellos ayudan a concluir que un plan o política de Estado no es un elemento de los crímenes de lesa humanidad.

De manera general, la discusión sumaria sobre el tema del plan o política de Estado por parte del Tribunal con relación tanto a los crímenes de lesa humanidad como al genocidio tiene tintes superficiales. De hecho, el resultado alcanzado - aquel según el cual no se requiere un plan o política de Estado- da la impresión de ser más una decisión política orientada a resultados que un análisis profundo de la historia de los dos crímenes o de sus fundamentos teóricos. Parece que el Tribunal también ha ignorado las historias de los borradores de los crímenes, así como los desarrollos posteriores, tal como el trabajo de la Comisión de Derecho Internacional.

La decisión del Tribunal de que no se necesita plan o política de Estado alguno para los crímenes de lesa humanidad ha demostrado ser más importante en el caso del genocidio. Por ejemplo, el caso Kunarac involucró la detención de mujeres civiles en condiciones aberrantes y de maltrato continuo, que incluían violaciones sexuales. Estos crímenes fueron cometidos por miembros de un grupo paramilitar organizado, pero no se atribuyeron necesariamente a un plan o política de Estado. Kunarac fue condenado por crímenes de lesa humanidad. Por lo tanto, ampliar el concepto de crímenes de lesa humanidad al eliminar cualquier requisito de un plan o política de Estado fue de gran importancia desde el punto de vista legal.

A decir verdad, la Sala de Apelaciones no ha negado la importancia de un plan o política al cometer genocidio y crímenes contra la humanidad. Por ejemplo, con relación al caso Krstić afirmó lo siguiente:

Si bien la existencia de dicho plan podría ayudar a determinar que el acusado poseía la intención genocida requerida, esto sólo es una prueba que apoya la inferencia de intención y no es por tanto un elemento del delito. De manera parecida, la Sala de Apelaciones ha rechazado el argumento de que los elementos legales de los crímenes de lesa humanidad (entre los que se encuentra el exterminio) necesitan prueba de la existencia de un plan o política para cometer dichos crímenes. La presencia de dicho plan o política puede ser prueba importante de que el ataque contra la población civil fue generalizado o sistemático, pero no es un elemento del crimen de lesa humanidad ${ }^{22}$. 
Eliminar el elemento del plan o política de Estado de los crímenes de lesa humanidad puede hacer que el concepto se aplique a un mayor número de actos criminales que van más allá de aquellos que son meramente aleatorios o aislados. En lugar de insistir en un plan o política de Estado, el elemento contextual para los crímenes de lesa humanidad depende solamente de su naturaleza «generalizada o sistemática». Sin embargo, esto puede generar que los crímenes de lesa humanidad sean aplicables a asesinos en serie, mafias, bandas de motociclistas y pequeños grupos terroristas, por ejemplo. Desde luego, este no fue el objetivo de la Comisión de Crímenes de Guerra de las Naciones Unidas, la Conferencia de Londres y el Tribunal Militar Internacional cuando el concepto de crímenes de lesa humanidad quedó definido legalmente al concluir la Segunda Guerra Mundial.

La primera codificación de los crímenes de lesa humanidad, en el artículo VI(c) del Estatuto del Tribunal Militar Internacional no establece de manera explícita un plan o política estatal como elemento de crímenes de lesa humanidad. Parece ser que esta es la razón por la cual la Sala de Apelaciones del Tribunal Penal Internacional para la Antigua Yugoslavia mencionó el artículo VI(c) como su primera fuente para proponer que no existía el elemento de plan o política de Estado en el Derecho internacional consuetudinario. ${ }^{23}$ Sin embargo, tal y como mencionamos anteriormente, el párrafo introductorio o chapeau del artículo VI del estatuto especifica que los acusados deben haber «actuado en interés de los países del Eje Europeo, como individuos o como miembros de organizaciones». Además, el llamado nexus, que exige que los crímenes de lesa humanidad sean cometidos «con relación a cualquier crimen dentro de la jurisdicción del Tribunal», tuvo el efecto de relacionarlos con los crímenes que, a su vez, están asociados con un plan o política estatal, a saber, crímenes de guerra o contra la paz. Puede que a los redactores del Estatuto del Tribunal Militar Internacional nunca se les ocurriera que los crímenes de lesa humanidad podrían ser aplicados a los hoy denominados «actores no estatales».

Por supuesto, es cierto que el propagandista nazi Julius Streicher fue acusado de crímenes de lesa humanidad por el Tribunal Militar Internacional a pesar de concluir que «las pruebas no consiguen establecer su conexión con la conspiración o un plan común para llevar a cabo una guerra agresiva, pues ya se ha definido la conspiración en otra parte de la sentencia ${ }^{24}$. Pero Streicher era un gauleiter o líder regional del partido, una posición que tenía cierta importancia dentro del régimen nazi. Además, los crímenes que cometió consistieron básicamente en hacer propaganda para la ideología nazi. Parece ser que hay que leer la sentencia con detenimiento para afirmar, tal como lo hizo la Sala de Apelaciones del Tribunal Penal Internacional para la Antigua 
Yugoslavia en el caso Kunarac, que su condena establece un referente en cuanto a que no existe elemento de plan o política de Estado con relación a los crímenes de lesa humanidad. Von Schirach es otro ejemplo esgrimido por la Sala de Apelaciones de Kunarac. Desde los años veinte, von Schirach fue el líder de las juventudes de Hitler. Durante la guerra, él fue el gauleiter de Viena, y fue condenado por crímenes de lesa humanidad por el Tribunal de Nuremberg a causa de las atrocidades cometidas durante la ocupación nazi ${ }^{25}$. Estas dos condenas en Nuremberg pueden apoyar la postura de que alguien que comete crímenes de lesa humanidad no necesita ser «una persona que cuente con información privilegiada» sobre el plan, pero no puede sustentar el argumento de que los crímenes de lesa humanidad no requieren un plan, algo que no faltaba en la Alemania nazi.

El Tribunal Militar Internacional nunca abordó directamente el tema de si un plan o política era un elemento de los crímenes internacionales que se estaban procesando, y la razón es obvia: el plan y política nazi de llevar a cabo una guerra agresiva y exterminar a los judíos de Europa sustentaban todo el caso. ¿Por qué el Tribunal tendría que haber hablado acerca de este tema teniendo en cuenta las circunstancias? Por las mismas razones, el juicio de Eichmann ${ }^{26}$ —otra fuente en la que se basó la Sala de Apelaciones de Kunarac - parece ser una autoridad poco sólida para sugerir que no es necesario el elemento del plan o de la política en los crímenes de lesa humanidad. Toda la sentencia de la Corte del Distrito de Jerusalén se basa en la prueba del plan o política nazi. Los jueces israelíes dictaminaron que Eichmann sabía «el secreto del plan de exterminio» desde mediados de 1941. Fue absuelto de genocidio por los actos cometidos antes de esa fecha ${ }^{27}$.

La mayor parte de los argumentos de la Sala de Apelaciones del caso Kunarac se basan en las definiciones literales de crímenes de lesa humanidad y genocidio, establecidas en el Estatuto del Tribunal Penal Internacional para la Antigua Yugoslavia, en el que no se plantea una referencia explícita a un plan o política de Estado. Aun así, puede decirse lo mismo de los términos «generalizado o sistemático» que la Sala de Apelaciones del caso Kunarac mantiene es el elemento contextual definitorio de crímenes de lesa humanidad. En la sentencia de Nuremberg, aunque de manera general, se utilizaron a menudo las palabras «generalizado» $\mathrm{y}$ «sistemático», aplicables a todas las atrocidades nazis, y de ninguna manera como elemento definitorio de crímenes de lesa humanidad. En el caso Eichmann, la palabra «generalizado» solamente aparece una vez («El acusado dirigió un grupo generalizado de oficiales», en el párrafo 231), y no se utilizó la palabra «sistemático». Si el hecho de que la Sala de Apelaciones de Kunarac no encontrara el elemento de «un plan o política» en los casos de Nuremberg y Eichmann es 
motivo para rechazar su importancia dentro del Derecho internacional consuetudinario, ino puede decirse lo mismo acerca de «generalizado o sistemático»?

Un importante y obvio descuido en el análisis de la Sala de Apelaciones apareció en la famosa nota a pie de página en el caso Kunarac acerca de este importante tema. Es el artículo 7(2)(a) del Estatuto de Roma, que establece que los crímenes de lesa humanidad deben cometerse durante un «ataque dirigido contra cualquier población civil» que «continúa o respalda una política de Estado u organizacional a fin de perpetrar dicho ataque ${ }^{28}$. La Sala de Apelaciones no ha dudado en citar el Estatuto de Roma como la autoridad en cuanto al Derecho internacional consuetudinario cuando ello guarda relación con su propio punto de vista sobre un tema particular. Por ejemplo, en el caso Tadić, cuando enunciaba la teoría de «empresa criminal conjunta», la Sala de Apelaciones del Tribunal Penal Internacional para la Antigua Yugoslavia hizo referencia al artículo 25(3)(d) del Estatuto de Roma como prueba importante de opinio juris de los Estados y, por lo tanto, del Derecho consuetudinario ${ }^{29}$. Por supuesto, el artículo 7(2) (a) del Estatuto de Roma deja espacio para la interpretación, pero no puede haber duda de que impone algún tipo de elemento contextual que involucra un plan o política. Por lo menos la sugerencia que aparece en el Estatuto de Roma en cuanto a que los crímenes de lesa humanidad contienen este requisito de plan o política debería haber sido abordado en cualquier análisis razonablemente exhaustivo de la cuestión.

Otro descuido a destacar en el debate sobre este tema de la Sala de Apelaciones de Kunarac son algunas de las decisiones nacionales más significativas que tratan crímenes de lesa humanidad. Se citaron tres casos canadienses de tribunales inferiores, aunque no se hizo mención alguna al caso más importante de crímenes de lesa humanidad en ese momento en la Corte Superior de Canadá. El fallo Finta de la Corte Superior de Canadá ya había sido utilizado anteriormente por la Sala de Apelaciones del Tribunal Penal Internacional para la Antigua Yugoslavia para el caso Tadić, en el cual las opiniones del Tribunal coincidían con las de la Corte Suprema ${ }^{30}$. Sin embargo, con relación a la materia de la política estatal, el caso Finta no fue de gran ayuda para la Sala de Apelaciones, y simplemente fue ignorado. En este caso, la mayoría de la Corte Suprema de Canadá afirmó que «una política o acción estatal» era un requisito previo de elemento jurídico en los crímenes de lesa humanidad ${ }^{31}$. De forma similar, al aplicar el code pénal francés, el cual exige pruebas de que los crímenes de lesa humanidad estuvieran «organizados al ejecutar un plan acordado previamente contra un grupo 
dentro de la población civil» ${ }^{32}$, los casos franceses han considerado que ello exige un plan o política estatal ${ }^{33}$.

Entre las autoridades que menciona la Sala de Apelaciones de Kunarac para apoyar su postura de que no existe el elemento de plan o política, destacan el Informe del Secretario General para el Consejo de Seguridad sobre el Proyecto de Estatuto del Tribunal Penal Internacional para la Antigua Yugoslavia. La nota a pie de página en Kunarac menciona los párrafos 47 y 48 de dicho informe como prueba de un «apoyo abrumador» al argumento de que no se requiere un plan o política estatal bajo el Derecho internacional consuetudinario. El texto de los dos párrafos, a continuación:

47. Los crímenes de lesa humanidad fueron reconocidos por primera vez en el Estatuto y la Sentencia del Tribunal de Nurenberg, además de la Ley $\mathrm{N}^{\circ} 10$ del Consejo de Control para Alemania. Los crímenes de lesa humanidad están dirigidos contra cualquier población civil y están prohibidos, sin que importe si se cometieron en un conflicto armado, de carácter internacional o interno.

48. Los crímenes de lesa humanidad hacen referencia a actos inhumanos de naturaleza muy grave, tales como asesinato premeditado, tortura o violación sexual, cometidos como parte de un ataque generalizado o sistemático contra cualquier población civil por motivos de nacionalidad, políticos, étnicos, raciales o religiosos. En el conflicto en el territorio de la antigua Yugoslavia, estos actos inhumanos tomaron la forma de «limpieza étnica» y violación generalizada y sistemática, así como otras formas de ofensas sexuales, incluyendo la prostitución forzada ${ }^{34}$.

¿Realmente estos dos lacónicos párrafos proporcionan un «apoyo abrumador» para la postura de la Sala de Apelaciones de Kunarac?

La nota a pie de página en el caso Kunarac también se refiere a la propuesta de 1954 del Código de Crímenes contra la Paz y la Seguridad de la Humanidad, elaborado por la Comisión de Derecho Internacional como una autoridad que comparte su opinión de que no existe ningún elemento de plan o política de Estado. En realidad, pareciera que es todo lo contrario. La propuesta de 1954 de la definición de crímenes de lesa humanidad de la Comisión afirma lo siguiente: «Los actos inhumanos tales como asesinato, exterminio, esclavitud, deportación o persecución que se cometan contra cualquier población civil por razones sociales, políticas, raciales, de religión o cultura, por las autoridades de un Estado o por individuos particulares actuando bajo instigación o con la tolerancia

(n)


de dichas autoridades» ${ }^{35}$. Los miembros de la Comisión habían intentado reformular la definición de Nuremberg de crímenes de lesa humanidad para eliminar el requisito de conexión con un conflicto armado. En realidad, votaron para eliminar el nexo con el conflicto armado, aunque en un principio no lo sustituyeron ${ }^{36}$. En la siguiente reunión, después de una noche de reflexión, los miembros de la Comisión se dieron cuenta de que, sin el elemento de conflicto armado, era difícil distinguir entre crímenes de lesa humanidad y crímenes corrientes. Por lo tanto, decidieron reconsiderar su anterior decisión ${ }^{37}$ y votaron, en consecuencia, para añadir las palabras «actos inhumanos por las autoridades de un Estado o por individuos particulares actuando bajo instigación o con la tolerancia de dichas autoridades contra cualquier población civil ${ }^{38}$. Según el informe de la Comisión de Derecho Internacional, «a fin de no identificar cualquier acto inhumano cometido por un individuo como crimen internacional, fue necesario añadir que dicho acto constituye un crimen internacional solamente si es cometido por un individuo instigado o dirigido por las autoridades de un Estado» ${ }^{39}$.

La Comisión Internacional de Derecho no revisó la propuesta del código durante casi treinta años. En los años ochenta, hubo intentos extravagantes de lograr una codificación progresiva, hasta que, en un momento determinado, se decidió abandonar por completo la clasificación de crímenes de lesa humanidad ${ }^{40}$. Básicamente, la Comisión reformuló los crímenes de lesa humanidad como un concepto «paraguas» que hacía referencia a las violaciones graves o sistemáticas de los derechos humanos. El tema de política de Estado fue raramente discutido durante este período, pese a que, en la medida en que la Comisión se había centrado en las violaciones de derechos humanos, puede afirmarse que la participación del Estado podía haber sido considerada como sine qua non.

Cuando se redactó la versión final del Código de Crímenes contra la Paz y la Seguridad de la Humanidad, en 1996, la Comisión de Derecho Internacional revisó profundamente su propuesta anterior y afirmó que el propósito del umbral en los crímenes de lesa humanidad es excluir «un acto al azar» $\mathrm{O}$ «un acto inhumano asilado» ${ }^{41}$. Pese a que el comentario no mencionó de manera explícita «los actores no estatales» ni proporcionó ningún ejemplo que ayudara a comprender su punto de vista, señaló que «la instigación o dirección por parte del Gobierno o cualquier

35 Proyecto de Código de Crímenes contra la Paz y la Seguridad, Documento de las Naciones Unidas, A/2693. 36 Documento de las Naciones Unidas, A/CN.4/SR.267, párrafo 59.

37 Documento de las Naciones Unidas, A/CN.4/SR.268, párrafo 11.

38 Documento de las Naciones Unidas, A/CN.4/SR.270, párrafo 36.

39 Informe de la Comisión de Derecho Internacional para la Asamblea General, Documento de las Naciones Unidas, A/2693.

40 InformedelaComisión de Derecholnternacionalsobreeltrabajodel $43^{\circ}$ período desesiones(29 deabril-19 de julio de 1991), Documento de las Naciones Unidas, A/46/10, párrafo 176.

41 E.g., Fiscalía v. Tadić (caso N ${ }^{\circ}$ IT-94-1-T), dictamen y sentencia, 7 de mayo de 1997, párrafo 648. El término «acto cometido al azar» también se ha utilizado en diversas sentencias sin el conocimiento de la Comisión de Derecho Internacional: Fiscalía v. Akayesu (caso N ${ }^{\circ}$ ICTR-96-4-T), sentencia, 2 de septiembre de 1998, párrafo 579; Fiscalía v. Blaškić (caso $\mathrm{N}^{\circ}$ IT-95-14-A) sentencia, 29 de julio de 2004, párrafo 202, supra nota 376; Fiscalía v. Erdemović (caso $\mathrm{N}^{\circ}$ IT-96-22-A), dictamen conjunto independiente del juez McDonald y del juez Vohrah, 7 de octubre de 1997, párrafo 22. 
organización o grupo que esté o no relacionado con un Gobierno, otorga al acto su gran dimensión y lo convierte en un crimen de lesa humanidad imputable a personas individuales o a agentes del Estado» ${ }^{42}$. La Comisión apoyó esta idea al citar la sentencia de Nuremberg, sobre todo las condenas contra Streicher y von Schirach. La explicación parece ser que estas personas fueron absueltas de crímenes contra la paz porque no contaban con información privilegiada de los grupos nazi. Pero incluso si Streicher y von Schirach eran «actores no estatales», en el sentido que no formaban parte del círculo cercano de Hitler, sus actos no se cometieron al azar o aisladamente, precisamente porque formaban parte del plan o política nazi de perseguir a minorías, como ya se ha explicado anteriormente en este artículo.

\section{GENOCIDIO: ¿INTENCIÓN ESPECÍFICA, O PLAN O POLIITICA?}

Con relación al genocidio, resulta claro que en ninguna parte del texto la definición de genocidio identifica de manera explícita un plan o política como indicio de este crimen. El genocidio fue definido por primera vez en el artículo II de la Convención de Ginebra de 1948, aunque una disposición en esencia idéntica aparece en documentos tan modernos como el Estatuto del Tribunal Penal Internacional para la Antigua Yugoslavia, el Estatuto del Tribunal Penal Internacional para Ruanda y el Estatuto de Roma de la Corte Penal Internacional. Durante la elaboración de la Convención contra el Genocidio de 1948, se rechazaron las propuestas que incluían el requisito explícito de que el genocidio fuera planeado por un gobierno ${ }^{43}$. Sin embargo, si bien no pueden descartarse las excepciones teóricas, resulta prácticamente imposible imaginar un genocidio que no ha sido planeado y organizado por el mismo Estado, por una entidad cuasi estatal o por alguna camarilla relacionada con ella. Raphael Lemkin fue el primer académico en proponer el concepto de genocidio en su libro Axis Rule in Occupied Europe, y hablaba con frecuencia de un plan como si fuera una condición sine qua non para el crimen de genocidio ${ }^{44}$. En el caso de Kayishema y Ruzindana, una Sala de Primera Instancia del Tribunal Penal Internacional para Ruanda escribió lo siguiente: «Si bien un plan específico para destruir no constituye un elemento de genocidio, parece que no es fácil llevar a cabo el genocidio sin un plan u organización» ${ }^{45}$. Además, dijo que «la existencia de dicho plan sería una prueba contundente del requisito de intención específica para el crimen de genocidio» ${ }^{46}$.

\footnotetext{
42 InformedelaComisión de DerecholnternacionalsobreelTrabajodel $48^{\circ}$ períododesesiones, 6 demayo-26 de julio de 1996, Documento de las Naciones Unidas, A/51/10, artículo 18, párrafo 5.

43 Documento de las Naciones Unidas, E/AC.25/SR.4, pp. 3-6. También en Kadic v. Karadzic, 70 F.3d 232 (2do Cir. 1995), cert. denegada, 64 USLW 3832 (18 de junio de 1996).

44 Lemkin, Raphael. Axis Rule in Occupied Europe. Analysis of Government, Proposals for Redress. Washington,

D.C.: Carnegie Endowment for International Peace, Division of International Law., 1944.

45 Fiscalía v. Kayishema et al. (caso N ICTR-95-1-T), sentencia, 21 de mayo de 1999, párrafo 94.

46 lbid., párrafo 276.
}

LA POLÍTICA DE ESTADO COMO ELEMENTO DE LOS CRÍMENES INTERNACIONALES 
El comentario de 1996 de la Comisión de Derecho Internacional sobre el Proyecto de Código de Crímenes contra la Humanidad parecía admitir que un plan o política estatal era primordial para el crimen de genocidio:

El grado de conocimiento acerca de los detalles de un plan o política para perpetrar el crimen de genocidio variaría según la posición que el perpetrador tenga dentro de la jerarquía del gobierno o de la estructura militar. Ello no significa que un subordinado que de hecho ejecuta el plan o política no pueda ser declarado culpable del crimen de genocidio simplemente porque no poseía el mismo grado de información con relación al plan o política general que sus superiores. La definición del crimen de genocidio requiere un grado de conocimiento del objetivo final de la conducta criminal en lugar de conocer todos los detalles, en conjunto, del plan o política de genocidio ${ }^{47}$.

Los Elementos de los Crímenes adoptados por la Asamblea de los Estados Parte de la Corte Penal Internacional en septiembre de 2002 incluyen el siguiente elemento del crimen de genocidio: «los hechos tuvieron lugar en el contexto de un patrón claro de conducta parecida dirigida contra ese grupo o fue un hecho que en sí mismo pudo producir dicha destrucción» ${ }^{48}$. Los Elementos de los Crímenes evitaron las palabras «plan»o «política», y se optó por «un patrón claro de conducta similar», aunque cualquier diferencia entre las dos expresiones sería principalmente semántica. De manera sorprendente, la Sala de Apelaciones del Tribunal Penal Internacional para la Antigua Yugoslavia no tuvo en cuenta, ni en Jelisic ni en Kunarac, esta evidencia más bien convincente de opinio juris para la presencia de un plan o política de Estado con relación al genocidio y — por analogía — a los crímenes de lesa humanidad ${ }^{49}$.

\section{LIMITANDO LA RESPONSABILIDAD DEL ESTADO Y LA RESPONSABILIDAD PENAL INDIVIDUAL}

La evidencia clara de por qué un plan o política de Estado es tan importante para determinar el crimen de genocidio aparece en el informe de la Comisión de Investigación sobre Darfur, establecida a finales de 2004 a instancias del Consejo de Seguridad y presidida por el experto legal internacional Antonio Cassese. Para responder la pregunta del Consejo de Seguridad sobre si actos de genocidio ocurrieron o no ${ }^{50}$, la Comisión afirmó que «el Gobierno de Sudán no persiguió una política de genocidio». Para explicar su postura, la Comisión afirmó lo siguiente:

47 InformedelaComisión de Derecholnternacional sobreelTrabajodel48ºperíododesesiones, 6 mayo-26 de julio de 1996, Documento de las Naciones Unidas, A/51/10, p. 90.

48 InformedelaComisiónPreparatoriaparalaCortePenallnternacional,apéndice,textodelborradorterminado de los Elementos del Crimen, Documento de las Naciones Unidas, PCNICC/2000/INF/3/Add.2.

49 Enunasentenciaposterior,laSaladeApelaciones determinóqueladefinición degenocidioadoptadaenlos Elementos delCrimen «noreflejabaelderechoconsuetudinariotaly comoestabacuando Krsticcometióel crimen». Fiscalía v. Krstic (caso N ${ }^{\circ}$ IT-98-33-A), sentencia, 19 de abril de 2004, párrafo 224.

50 Documento de las Naciones Unidas, S/RES/1564 (2004). 
Sin embargo, parece obviarse un elemento fundamental, por lo menos en lo que respecta a las autoridades gubernamentales centrales: la intención genocida. En líneas generales, la política de atacar, asesinar y desplazar forzosamente a miembros de algunas tribus no muestra una intención específica de aniquilar, total o parcialmente, un grupo por motivos de su nacionalidad, raza, etnicidad o religión. En su lugar, pareciera que los que planearon y organizaron los ataques a los poblados tenían la intención de sacar a las víctimas de sus hogares, principalmente por motivos de la guerra de contrainsurgencia ${ }^{51}$.

La Comisión no se opuso a la jurisprudencia de la Sala de Apelaciones del Tribunal Penal Internacional para la Antigua Yugoslavia y no desestimó la posibilidad de que una persona, actuando sola, pudiese cometer actos genocidas ${ }^{52}$. Sin embargo, en la práctica, intentó responder a la pregunta del Consejo de Seguridad, es decir, a si se cometieron actos genocidas en Darfur, analizando si la evidencia apuntaba a la existencia de un plan o política ideado por el estado sudanés. Un fenómeno similar aparece en la sentencia de 2007 de la Corte Internacional de Justicia, en la demanda presentada por Bosnia y Herzegovina contra Serbia y Montenegro, según el artículo IX de la Convención sobre Prevención y Castigo del Crimen de Genocidio. La Corte discutió si la política de Serbia y sus aliados bosnios fue de limpieza étnica o de genocidio ${ }^{53}$.

Tanto la Comisión de Darfur como la Corte Internacional de Justicia estudiaron el genocidio desde una perspectiva que incluía la responsabilidad del Estado dentro de su ámbito. Si estas aceptaron verdaderamente la teoría según la cual el genocidio no requiere un plan o política de Estado, y según la cual el genocidio puede ser cometido por un único perpetrador, habrían buscado pruebas de que un solo individuo, cuyos actos no fueran atribuibles a Sudán o a Serbia, había matado a un miembro de uno de los grupos objetivo, con la intención de destruirlo en todo o en parte. Sin embargo, la Comisión de Darfur interpretó la petición del Consejo de Seguridad de «determinar si los actos de genocidio habían ocurrido o no» en el sentido de determinar si Sudán tuvo o no un plan o política para cometer dichos actos. La Corte Internacional de Justicia razonó de forma similar.

Ambos organismos intentaron aplicar la definición de genocidio mencionada en el artículo II de la Convención contra el Genocidio de 1948. En ella se describe el genocidio como uno de cinco actos sancionables, que incluyen el asesinato «cometido con la intención de destruir, total o parcialmente, a un grupo nacional, étnico, racial o religioso, como tal». Estas palabras distinguen entre el genocidio y los homicidios comunes. Las sentencias de los tribunales penales internacionales están llenas de

51 InformedelaComisiónInternacionaldelnvestigaciónsobreViolacionesdelDerechoHumanitariolnternacional y los Derechos Humanos en Darfur, Documento de las Naciones Unidas, S/2005/60, párrafo 518. 52 lbid., párrafo 520.

53 Casorelacionadocon la Aplicación dela Convención sobrelaPrevenciónyel Castigo del Crimen Genocida (Bosnia y Herzegovina v. Serbia y Montenegro), sentencia, 26 de febrero de 2007, párrafo 190. 
declaraciones que señalan que el elemento que define el genocidio es «la intención específica», o la «intención especial» o, según los juristas europeos, su dolus specialis. La Comisión de Darfur lo describió como «una intención criminal agravada o dolus specialis: ello implica que el perpetrador deseó de manera consciente que los actos prohibidos que cometió dieran como resultado la destrucción, total o parcial, del grupo como tal, y sabía que sus actos destruirían, total o parcialmente, dicho grupo como tal $\aleph^{54}$. De hecho, la Comisión relacionó el concepto de política con el de intención específica: «En líneas generales, la política de atacar, asesinar y desplazar forzosamente a miembros de algunas tribus, no prueba una intención específica de aniquilar, total o parcialmente, a un grupo nacional, étnico, racial o religioso ${ }^{55}$.

Para la Corte Internacional de Justicia, los actos deben cometerse «con la intención específica necesaria (dolus specialis), es decir, con la voluntad de destruir el grupo, a diferencia de desplazarlo de la región» ${ }^{56}$. La Corte concluyó que «se ha demostrado de manera contundente que los asesinatos masivos de miembros del grupo protegido se cometieron con la intención específica (dolus specialis) de parte de los perpetradores de destruir, total o parcialmente, el grupo como tal $»^{57}$. Noten que la Corte se refirió a «los perpetradores» en un sentido colectivo. Existe, en el párrafo 292 de la sentencia, un debate particularmente interesante acerca de la intención específica dentro del contexto de la masacre de Srebrenica:

El concepto de intención ha sido ejemplificado por la Sala de Primera Instancia del caso Krstić. En sus conclusiones, estaba convencida sobre la existencia de intención, por las pruebas con las que contaban. Bajo el título «Plan para ejecutar a los hombres musulmanes bosnios de Srebrenica», la Sala «opina que, tras la toma de Srebrenica en julio de 1995, los serbio bosnios idearon y pusieron en marcha un plan para ejecutar al mayor número posible de civiles bosnios musulmanes en edad militar presentes en el lugar» (IT-98-33-T, Sentencia, 2 de agosto de 2001, párrafo 87).

Como puede verse, la Sala analiza el tema de la «intención específica» en términos de la existencia de un plan. Pero en el Derecho penal, este tema no es tan transparente. Aunque varias personas pueden participar en un plan común, esto no quiere decir necesariamente que todos compartan la misma intención específica.

\footnotetext{
54 InformedelaComisiónInternacionaldelnvestigaciónsobreViolacionesdelDerechoHumanitariolnternacional y los Derechos Humanos en Darfur, Documento de las Naciones Unidas, S/2005/60, párrafo. 491. 55 lbid., p. 4.

56 Casorelacionadoconlaaplicación delaConvenciónsobrelaPrevenciónyCastigodelCrimendeGenocidio (Bosnia y Herzegovina v. Serbia y Montenegro), sentencia, 26 de febrero de 2007, párrafo 190. 
En el caso Bosnia, el Estado demandante fue responsable de parte de la desaparición de la distinción entre intención específica y plan o política de Estado. La Corte comentó lo siguiente:

Que este argumento del Demandante se aparta de la intención de los perpetradores individuales de los supuestos actos de genocidio que se juzgan, para centrarse en la intención de una autoridad de mayor rango, tanto dentro de la VRS o de la Republika Srpska, como a nivel del Gobierno del propio Demandado. Al no existir una declaración oficial de objetivos que reflejen dicha intención, el Demandante argumenta que la intención específica (dolus specialis) de quienes dirigían las acciones queda clara por la consistencia de las prácticas, sobre todo en los campos, mostrando así que el patrón era aquel de actos cometidos «dentro de un marco institucional» ${ }^{58}$.

En efecto, Bosnia sostenía que la intención específica para cometer genocidio podría demostrarse mediante un patrón de actos perpetrados «dentro de un marco institucional organizado». La Corte consideró la evidencia de declaraciones oficiales por parte de oficiales serbio-bosnios, pero observó que «el argumento del Demandante no guarda relación con que un motivo esencial de la mayoría de los dirigentes serbio bosnios era crear un gran Estado serbio, mediante una guerra de conquista si era necesario, y que este motivo no requería necesariamente la destrucción de los musulmanes bosnios y otras comunidades, sino su expulsión ${ }^{59}$. Aquí la Corte agregó un ingrediente adicional al debate, la cuestión del «motivo». No obstante, nuevamente el término «política» resulta más adecuado para describir lo que se estaba debatiendo. Mezclando la intención específica y el plan o política una vez más, la Corte concluyó: «El dolus specialis, esto es, la intención específica para destruir el grupo, total o parcialmente, tiene que demostrarse de manera convincente, haciendo referencia a circunstancias particulares, a menos que pueda demostrarse de manera convincente la existencia de un plan general con ese fin ${ }^{60}$. Además, «el Demandante no ha establecido la existencia de esa intención por parte del Demandado, ya sea sobre la base de un plan concertado o basándose en que los hechos antes mencionados muestran un patrón consistente de conducta que no podría sino apuntar a la existencia de dicha intención ${ }^{61}$.

En realidad, ni la Comisión de Darfur ni la Corte Internacional de Justicia buscaban una intención específica por parte de los criminales individuales. Ellos buscaban, más bien, la «intención específica» de un Estado, como Sudán, o de una entidad cuasi estatal, como los «serbio bosnios». Pero los Estados no poseen intención específica; las personas sí. Los Estados tienen una política. El término «intención específica» se 
usa para describir lo investigado, aunque su verdadera materia es la política de Estado. Parece plausible, sin duda posible, que en una campaña de limpieza étnica llevada a cabo a gran escala bajo la instigación de un Estado habrá perpetradores que estarán tan motivados por el odio racial, que buscarán el exterminio físico del grupo perseguido. En otras palabras, actos que no tienen un fin genocida pueden ser perpetrados por grupos de personas, algunos de los cuales pueden tener una intención genocida. Sin embargo, resulta obvio que, cuando se les pregunta si «se cometieron actos genocidas», organismos como la Comisión de Darfur y la Corte Internacional de Justicia no llevan a cabo sus investigaciones teniendo en cuenta a estos marginales individuos. En lugar de ello, se tornan hacia la política.

Una importante dificultad legal en este caso gira en torno a la relación entre responsabilidad del Estado y responsabilidad penal individual. Parece que la Comisión de Darfur y la Corte Internacional de Justicia abordan este tópico a través de la ficción de que un Estado puede tener una intención específica. Podría ser más productivo revertir la lógica de este razonamiento. En lugar de un intento mecánico e insatisfactorio de aplicar al comportamiento de un Estado conceptos que pertenecen a la responsabilidad individual, sería mejor tomar la política del Estado como punto de partida e intentar relacionar este concepto con la culpabilidad individual. Siguiendo este enfoque, el primer punto a resolver para determinar si se ha cometido genocidio es saber si existe una política de Estado. Si la respuesta es afirmativa, entonces la investigación se traslada al individuo, sin que la pregunta central sea la intención de la persona, sino, más bien, el conocimiento que la persona tiene de la política. En cualquier circunstancia, la intención personal surge porque los actos específicos de genocidio, como el asesinato, contienen su propio elemento mental. Pero, en lo que respecta al plan o a la política, el conocimiento es la clave de la criminalidad.

Un obstáculo importante que este enfoque ayuda a resolver es el potencial que existe de obtener resultados diferentes con respecto a la responsabilidad del Estado y la responsabilidad penal individual. Sin embargo, también colabora en la solución de otro problema que ha sorprendido a jueces en los tribunales internacionales: el de la complicidad en el genocidio. Ellos han abordado la complicidad al condenar a los que ayudan a cometer el crimen en la medida en que el acusado conoce la intención del perpetrador ${ }^{62}$. De nuevo, no es muy real esperar que una persona conozca la intención de otra, especialmente cuando se está considerando la intención específica. Incluso las cortes deducirán la intención solamente a partir del comportamiento del perpetrador. La investigación parece tener más sentido y ser más eficiente cuando la pregunta planteada es si el cómplice tenía conocimiento de la política. Se condenó al general Krstić por complicidad porque la Sala 
de Apelaciones consideró que él estaba al tanto de la política llevada a cabo por el general Mladić, no porque se creyera que él leía la mente de Mladić y conocía su «intención específica».

Ciertamente, lo dicho genera la necesidad de una reconsideración radical de la definición de genocidio. Involucra incluir en la lectura de la definición adoptada en la Convención de 1948 un elemento que se encuentra allí, a lo sumo, por implicancia. No hay nada inadmisible en esto, desde el punto de vista de la interpretación de los tratados. Puede no estar justificada por los travaux préparatoires, pero, tal como el juez Shahabuddeen de la Sala de Apelaciones del Tribunal Penal Internacional para la Antigua Yugoslavia afirmó en su opinión disidente en Krstić, no debería posarse excesiva confianza en la historia de los borradores de tratados ${ }^{63}$. Confirmar la importancia de un plan o política de Estado como elemento del crimen de genocidio presenta muchas ventajas en términos de coherencia y política judicial.

Lo mismo puede decirse, por supuesto, de los crímenes de lesa humanidad. En una sentencia reciente que trató estos crímenes, la Corte Suprema de Canadá, que una década antes había afirmado que la política de Estado era un elemento de los crímenes de lesa humanidad ${ }^{64}$, hizo eco de los recientes avances en la jurisprudencia internacional. «Parece que actualmente no existe ningún requisito en el Derecho internacional consuetudinario que señale que una política debe subyacer el ataque, aunque no ignoramos la posibilidad de que el Derecho internacional consuetudinario evolucione a lo largo del tiempo para incorporar el requisito de una política», afirmó la Corte Suprema de Canadá65.

\section{ESTADO O POLÍTICA «ORGANIZACIONAL»}

Una objeción importante para dicha interpretación de genocidio $-\mathrm{y}$ de crímenes de lesa humanidad- es la exclusión de los actores no estatales. Este problema puede abordarse de una manera adecuada al crear un concepto amplio de «política de Estado», de manera que pueda aplicarse tanto a los actores no estatales como a los Estados en sentido formal. Organizaciones como la Republika Srpska, las FARC, la Autoridad Palestina y quizás el gobierno de Taiwán, mas no organizaciones como los Ángeles del Infierno o la mafia, serían tratados de esta manera.

Pero incluso fuera del contexto del Derecho internacional consuetudinario, este tema surgirá en la interpretación del artículo 7(2)(a) del Estatuto de Roma, con su referencia a un «plan o política de Estado u organizacional» como requisito contextual para los crímenes de lesa humanidad. Los diccionarios definen «organización» como cualquier 
grupo organizado de personas, tales como un club, una sociedad, un sindicato o una empresa. Seguramente los redactores del Estatuto de Roma no pretendían que el artículo 7 tuviera un alcance tan amplio, dado que, itoda la jurisprudencia anterior relacionada con crímenes de lesa humanidad, así como toda la evidencia de procesos nacionales por crímenes de lesa humanidad concernieron atrocidades apoyadas por un Estado? Si realmente querían incluir cualquier tipo de organización, tal como una «organización» bastante teórica de dos personas, ¿por qué incluyeron esas palabras? El problema más importante para los partidarios de este punto de vista más amplio es su incapacidad para explicar cómo debe calificarse el término «organización».

El catedrático Cherif Bassiouni, uno de los expertos más importantes en crímenes de lesa humanidad, explica lo siguiente en su más reciente trabajo de tres volúmenes, The Legislative History of the International Criminal Court (La historia legislativa de la Corte Penal Internacional):

Contrariamente a lo que algunos argumentan, el artículo 7 no representa un nuevo desarrollo para los crímenes de lesa humanidad, a saber, su aplicabilidad a los actores no estatales. Si ese fuera el caso, podría acusarse a la mafia de dichos crímenes ante la Corte Penal Internacional, y esa no es la literalidad ni el objetivo del artículo 7. La pregunta surgió después del 11/9, en cuanto a si un grupo como al-Qaeda, que opera a nivel mundial y es capaz de producir daño significativo en más de un Estado, encaja en esta categoría. Según este autor, este grupo no puede incluirse en la definición de crímenes de lesa humanidad tal y como los define el artículo 7 y, en este sentido, bajo ninguna definición de ese crimen hasta el artículo 6(c) del Tribunal Militar Internacional, a pesar de los peligros internacionales que esto representa [...] El texto [del artículo 7(2)] se refiere claramente a la política de Estado, y las palabras «política organizacional» no se refieren a la política de una organización, sino a la política de un Estado. No se refiere a los actores no estatales $[\ldots]^{66}$.

Puede que el profesor Bassiouni tenga ambiciones desmesuradas, ya que este enfoque excluye a los cuasi estatales. Tal como entiendo su posición, el término «organización» pretende vincular organismos con un Estado, como la Gestapo y la S.S. Otro comentarista experimentado, Antonio Cassese, escribe en su libro que uno de los «rasgos comunes» de los crímenes de lesa humanidad es que «no se trata de hechos aislados o esporádicos, sino que son parte de una política de gobierno o de una práctica generalizada y sistemática de atrocidades toleradas, condonadas o consentidas por un gobierno o autoridad de facto [...]» ${ }^{67}$.

66 Bassiouni, Cherif. The Legislative History of the International Criminal Court: Introduction, Analysis and Integrated Text. Volumen I. Ardsley, N.Y.: Transnational Publishers, 2005, pp. 151-152. Véase también del mismo autor Crimes Against Humanity. Segunda edición revisada. La Haya: Kluwer Law International, 1999, pp. 243-281.

67 CAssese, Antonio. International Criminal Law. Oxford: Oxford University Press, 2003, p. 64. 
En una época en la que la fiscal de la Corte Penal Internacional para la Antigua Yugoslavia parecía considerar que la política era un elemento esencial de los crímenes de lesa humanidad, propuso que no debía referirse únicamente a "política de Estado», sino que también podía referirse a organismos cuasi estatales. A continuación detallamos cómo fue explicado este argumento en 1997, con relación al caso Tadić:

Otro tema está relacionado con la naturaleza de la entidad que está detrás de la política. Tradicionalmente se pensaba, en realidad, no sólo que la política debía estar presente, sino que debía ser una política de Estado, como fue el caso en la Alemania nazi. La opinión dominante fue, tal como lo explicó un comentarista, que los crímenes de lesa humanidad, como crímenes de naturaleza colectiva, requieren una política de Estado «porque su comisión requiere el uso de instituciones, personal y recursos del Estado, para cometer, o no impedir que se cometan los crímenes específicos descritos en el artículo 6(c) [del Estatuto de Nurnberg ]». Si bien puede que este haya sido el caso durante la Segunda Guerra Mundial, y por lo tanto la jurisprudencia seguida por los tribunales que procesaban cargos de crímenes de lesa humanidad sobre actos que supuestamente habían ocurrido durante este periodo, la situación ya no es la misma. Como el primer tribunal internacional que consideró cargos de crímenes de lesa humanidad sobre supuestos hechos ocurridos después de la Segunda Guerra Mundial, el Tribunal Internacional no está limitado por la doctrina previa, sino que debe aplicar el Derecho internacional consuetudinario tal como se encontraba cuando ocurrieron los delitos. En este sentido, el Derecho relacionado con los crímenes de lesa humanidad, ha evolucionado para tener en cuenta fuerzas que, aunque no sean del gobierno legítimo, tienen control de facto, o pueden moverse libremente dentro de un territorio definido. La Fiscalía argumenta, en su presentación previa al juicio, que bajo el Derecho internacional, los crímenes de lesa humanidad pueden ser cometidos en nombre de entidades que ejercen un control sobre un territorio en particular, pero que no cuentan con reconocimiento internacional o estatus formal de Estado de jure, o por un grupo u organización terrorista. La defensa no cuestiona esta afirmación, lo cual coincide con recientes declaraciones relacionadas a crímenes de lesa humanidad. ${ }^{68}$

Si volvemos a los orígenes del concepto, a Nuremberg, parece claro que el fundamento para reconocer los crímenes de lesa humanidad fue castigar los crímenes autorizados por el Derecho nazi o tolerados por las autoridades. ¿No es esta la razón por la que el artículo VI(c) del Estatuto del Tribunal Militar concluye diciendo «[...] en violación o no del Derecho nacional de la corte donde fueron perpetrados [...]?». A lo largo de décadas, un fundamento básico para procesar los crímenes de lesa humanidad como tales ha sido que dichas atrocidades 
generalmente no son perseguidas en el Estado que normalmente ejerce jurisdicción, según los principios de personalidad activa o territorial, debido a la propia participación o aquiescencia del Estado. Los crímenes de atrocidad internacional ${ }^{69}$ y los crímenes de lesa humanidad, en particular, fueron creados de manera que dichos actos pudieran ser castigados en otro lugar y, por lo tanto, que la impunidad fuera abordada de manera efectiva.

Por lo general, no tenemos el mismo problema de impunidad con respecto a los «actores no estatales». La mayoría de Estados desean y pueden procesar a grupos terroristas, rebeldes, mafias, bandas de motociclistas y asesinos en serie que operan dentro de sus fronteras. Como mucho, el Derecho internacional ayuda principalmente en este caso en el área de asistencia legal mutua. Por ejemplo, existe poca utilidad real en definir «terrorismo» como un crimen internacional, ya que, como norma general, los Estados donde se cometen los crímenes desean y pueden procesar a los responsables. Normalmente tienen problemas para capturar a los delincuentes, pero este tema es tratado a través de cooperación internacional y no por definir los actos como crímenes internacionales, de manera que pueden estar sujetos a jurisdicción universal o establecer tribunales internacionales para que los procesen.

\section{EMPRESA CRIMINAL CONJUNTA, "CRÍMENES DE LARGA ESCALA»Y PLAN O POLÍTICA DE ESTADO}

Aunque no se identificó como tal en los estatutos de los tribunales ad hoc, los jueces han desarrollado un poderoso paradigma teórico de responsabilidad del cómplice que se conoce con el nombre de «empresa criminal conjunta». Al describir el concepto, la Sala de Apelaciones del Tribunal Penal Internacional para la Antigua Yugoslavia explicó que «la responsabilidad criminal internacional comprende acciones perpetradas por un grupo de acuerdo a un patrón criminal común» ${ }^{70}$. Es parecido a los conceptos conocidos de complicidad con un propósito común en los sistemas legales nacionales. Según autoridades recientes, el enfoque tiene sus orígenes en el Derecho internacional consuetudinario, tal como lo demuestra la referencia a los procesos llevados a cabo tras la Segunda Guerra Mundial ${ }^{71}$, al artículo 25(3)(d) del Estatuto de Roma de la Corte Penal Internacional y a la disposición en la que se basa, y el artículo 2(3)(c) de la Convención Internacional para la Supresión de Bombardeos Terroristas ${ }^{72}$.

69 Scheffer, David. «The Merits of Unifying Terms: 'Atrocity Crimes' and 'Atrocity Law'». Genocide Studies and Prevention $\mathrm{N}^{\circ}$ 2, p. 91.

70 Fiscalía v. Tadić (caso N IT-94-1-A), sentencia, 15 de julio de 1999, párrafo 193.

71 lbid., párrafos 195-220.

72 lbid., párrafos 221-222. Véase también Fiscalía v. Krnojelac (IT-97-25-A), sentencia, 17 de septiembre de 2003, párrafo 29; Fiscalía v. Milutinović et al. (IT-99-37-AR72), decisión sobre la potestad para impugnar la moción de Draguljob Ojdanic - empresa criminal conjunta, 21 de mayo de 2003, párrafos 19-20. 
En la apelación de la sentencia Tadić, la Sala de Apelación del Tribunal Penal Internacional para la Antigua Yugoslavia comentó que a menudo «la criminalidad colectiva» implicará situaciones en las que todos los coacusados, al actuar según un diseño común, posean la misma intención criminal. No obstante, existen atrocidades en las que uno de los perpetradores comete un acto que, si bien está fuera del diseño o patrón común, fue, no obstante, una consecuencia natural y previsible de lograr dicho propósito común. Un ejemplo sería una intención común y compartida, por parte de un grupo, de desplazar a la fuerza a miembros de un grupo étnico de su pueblo, ciudad o región — para lograr una «limpieza étnica»— y, como consecuencia, en el transcurso de dicha acción, se dispara y mata a una o más víctimas. Si bien no se ha reconocido el asesinato de manera explícita como parte de un diseño o patrón común, era predecible que el desplazamiento forzoso de civiles a punta de pistola podía causar la muerte de uno o más de dichos civiles. La responsabilidad criminal puede imputarse a todos los participantes de una empresa común en la que el riesgo de que se produjeran muertes era una consecuencia predecible de la ejecución de un diseño común y el acusado fue imprudente o indiferente a dicho riesgo ${ }^{73}$.

La Sala de Apelaciones ha descrito esto como una «ampliación» de responsabilidad de empresa criminal conjunta ${ }^{74}$. El caso Tadić admitió las tres categorías de responsabilidad de empresa criminal conjunta. La primera categoría comprende casos en los que todos los coacusados, según un diseño o patrón común, poseen la misma intención criminal ${ }^{75}$. La segunda categoría es similar a la primera, y el propósito común se aplica «a ejemplos en los que se supone que los delitos procesados fueron cometidos por miembros de unidades militares o administrativas, como las que dirigen los campos de concentración ${ }^{76}$. Tanto en la primera como en la segunda categoría, el participante debe tener una intención criminal para cometer dicho crimen. Solamente en la tercera categoría «ampliada», se requiere que el acto sea una consecuencia predecible de lograr el propósito común, que es un estándar de conocimiento esencialmente objetivo. En otras palabras, la tercera categoría permite condenar a una persona que no tenía realmente intención de cometer el crimen o que no sabía que sus cómplices lo iban a cometer.

La doctrina de la empresa criminal conjunta se mencionó por primera vez en un caso relacionado con un delincuente de rango menor, quien se unió a unos cómplices en un asalto a un pueblo como parte de una campaña de limpieza étnica. Dusko Tadić fue absuelto por la Sala de Primera Instancia de cinco asesinatos cometidos por sus cómplices en Jaskici porque no se demostró que él personalmente tuviera la intención

73 Fiscalía v. Tadić (caso N IT-94-1-A), sentencia, 15 de julio de 1999, párrafo 204.

74 Fiscalía v. Ntakirutimana etal. (caso N ${ }^{\circ}$ ICTR-96-10-A y ICTR-96-17-A), sentencia, 13 de diciembre de 2004, párrafo 465.

75 Fiscalía v. Tadić (caso N IT-94-1-A), sentencia, 15 de julio de 1999, párrafo 196.

76 Ibid., párrafo 202. 
de cometerlos ${ }^{77}$, pero se desestimó el veredicto y la Sala de Apelaciones dictó una condena basándose en la teoría de la empresa criminal conjunta $^{78}$. El contexto de este juicio, que tenía muchas características en común con anteriores juicios relacionados con delincuentes que ocupaban puestos de poca importancia dentro de la jerarquía criminal, complementaba las descripciones legales del concepto de empresa criminal conjunta. El paradigma jurídico para la empresa criminal conjunta fue una banda de ladrones de banco, no un partido nazi.

Obviamente había un gran potencial para la teoría de empresa criminal conjunta en los casos más importantes. Esto no se alegó en la primera acusación de Slobodan Miloševicic ${ }^{79}$, que se emitió varias semanas antes de la apelación de la sentencia de Tadić. Pero más tarde el Fiscal corrigió las alegaciones para condenar:

[...] la participación de una empresa criminal conjunta como coperpetrador. El propósito de esta empresa criminal conjunta fue, inter alia, la expulsión de una parte importante de la población albano kosovar del territorio de la provincia de Kosovo en un intento por asegurar la continuación del control serbio sobre la provincia. Para cumplir con el propósito criminal, cada uno de los acusados, actuando de manera individual o en complicidad el uno con el otro y con otros conocidos o no, contribuyeron de manera significativa a la empresa criminal conjunta mediante el uso de los poderes de jure y de facto que tenía a su disposición ${ }^{80}$.

No obstante, no se había puesto en práctica la aplicación de la empresa criminal conjunta en casos importantes hasta el veredicto del caso de uno de los serbio-bosnios más importantes, Radoslav Brđanin, en septiembre de 2004 ${ }^{81}$. Entre sus múltiples responsabilidades, fue presidente del «Grupo de Crisis» de la Región Autónoma de Krajina. Basándose en varias formulaciones previas de la Sala de Apelaciones, la Sala de Primera Instancia concluyó que no podía aplicarse la teoría de la empresa criminal conjunta y sostuvo que el principal perpetrador de un acto criminal debe ser miembro de dicha empresa ${ }^{82}$. En consecuencia, la sentencia limitó la doctrina a grupos pequeños y excluyó su importancia en casos de planes criminales de gran escala en los que el principal perpetrador podría desconocer las intenciones finales de líderes y organizadores.

La Sala de Apelaciones revocó las conclusiones de la Sala de Primera Instancia al afirmar que la empresa criminal conjunta se aplicaba no solamente a «casos menores» sino también a empresas criminales de gran

77 Fiscalía v. Tadić (caso $\mathrm{N}^{\circ}$ IT-94-1), dictamen y sentencia, 7 de mayo de 1997, párrafo 373.

78 Fiscalía v. Tadić (caso $\mathrm{N}^{\circ}$ IT-94-1-A), sentencia, 15 de julio de 1999, párrafos 233-234.

79 Fiscalía v. Milošević et al. (caso N IT-99-37-I), decisión sobre la revisión de la acusación y aplicación de las sentencias consiguientes, 24 de mayo de 1999.

80 Fiscalía v. Milošević et al. (caso $\mathrm{N}^{\circ}$ IT-99-37-PT), segunda acusación corregida, párrafo 16.

81 Fiscalía v. Brđanin (caso N $^{\circ}$ IT-99-36-T), sentencia, primero de septiembre de 2004.

82 lbid., párrafos 355-356. 
escala que involucraban a los perpetradores o delincuentes principales quienes se encuentran personalmente fuera del plan común. Al hacer referencia a los dos casos posteriores a la Segunda Guerra Mundial, la Sala de Apelaciones afirmó que encontró clara evidencia para imponer la responsabilidad criminal sobre un acusado por participar en un propósito criminal común, «donde la conducta que implica el actus reus criminal es perpetrada por personas que no comparten un propósito común». No se requiere probar «que existía un conocimiento o acuerdo para cometer el crimen en cuestión entre el acusado y el perpetrador principal del crimen ${ }^{83}$.

Una de las doctrinas en las que se basó la Sala de Apelaciones del caso, Brđanin, conocido como el Justice Case ('caso justicia'), involucró el juicio de importantes jueces, magistrados y fiscales por su papel en la creación de la política racista y genocida nazi ${ }^{84}$. La Sala de Apelaciones mencionó una de las conclusiones de dicho caso: «Los hechos materiales que deben probarse en cada caso son (1) existencia de un patrón o plan importante de persecución y exterminio racial y (2) comportamiento específico del acusado en particular para lograr el plan. Esto no es más que la aplicación de conceptos generales del Derecho penal $»^{85}$. La Sala de Apelaciones estuvo fuertemente inspirada por el análisis del juez Iain Bonomy, en un dictamen independiente de un fallo preliminar en el caso Milutinović el año anterior. El juez Bonomy también analizó el Caso Justicia y afirmó:

El Tribunal Militar parece haber encontrado responsabilidad criminal en los dos acusados por su participación en el plan criminal común, a pesar que no perpetraron el actus reus de los crímenes por los que fueron acusados; en su lugar, el actus reus fue perpetrado por verdugos que simplemente cumplieron con lo ordenado por la corte. El Tribunal no analizó el estado mental de los verdugos que ejecutaron las condenas a muerte impuestas como resultado de las acciones de Lautz, Rothaug y los otros participantes en el plan común, o si dichas personas tenían conocimiento de que los asesinatos formaban parte de un plan para corromper la ley con el fin de exterminar a los judíos y a otras «personas indeseables» ${ }^{86}$.

El otro caso posterior a la Segunda Guerra Mundial mencionado por la Sala de Apelaciones y discutido por el juez Bonomy en su dictamen independiente involucraba a la Oficina Principal de la SS para la Raza y la Colonización, y se conoce con el nombre de caso RuSHA (por sus siglas en alemán). Se acusó a los líderes de la RuSHA de participar en

83 Fiscalía v. Brđanin (caso № IT-99-36-A), sentencia, 3 de abril de 2007, párrafo 394.

84 Los Estados Unidos de América v. Alstötter et al. (Justice Case), (1948) 3 TWC 1, 6 LRTWC 1, 14 ILR 278 (Tribunal Militar de los Estados Unidos).

85 lbid., p. 1063(TWC), citado en Fiscalía v. Brđanin (caso N IT-99-36-A), sentencia, 3 de abril de 2007, párrafo 397.

86 Fiscalíav. Milutinović etal.(caso N IT-05-87-PT), dictamen independientedeljuezlain Bonomy,22demarzo de 2006, párrafo 20. 
un «programa sistemático de genocidio» ${ }^{87}$. Tal y como el juez Bonomy mencionó:

El Tribunal Militar encontró que la Fiscalía estableció que entre Hitler, Himmler (el líder de la SS) y otros oficiales nazis existió «un objetivo con la doble finalidad de debilitar y, finalmente, destruir otras naciones, al mismo tiempo que Alemania se fortalecía biológica y territorialmente, a expensas de las naciones conquistadas». Además, concluyó que los líderes de la RuSHA (y en particular de los acusados Hofmann y Hildebrandt) se unieron y participaron de manera entusiasta en la ejecución del plan de «germanización» $[\ldots]^{88}$.

La Sala de Apelaciones concluyó lo siguiente:

La Sala de Apelaciones determina que de la discusión del Tribunal Militar, sobre los diferentes aspectos del plan de germanización, tanto Hofmann como Hildebrandt, en calidad de líderes de la RuSHA, trabajaron de manera conjunta e intensa con Himmler, Kaltenbrunner y otros altos oficiales de la SS al ultimar los detalles de cómo iba a ejecutarse el plan, especialmente en lo relacionado con los programas de abortos y secuestros. Teniendo en cuenta la participación activa que tuvieron en este plan y su conocimiento de las actividades llevadas a cabo para lograrlo, ambos acusados fueron declarados responsables por la conducta de los agentes de la RuSHA que cometieron los crímenes, sin discutir si los principales perpetradores sabían que sus acciones formaban parte del plan de germanización o si existía un acuerdo entre los acusados y estos agentes ${ }^{89}$.

La Sala de Apelaciones del caso Brđanin también comentó que la mayor parte de la jurisprudencia anterior trataba sobre empresas criminales conjuntas de menor envergadura y, por lo tanto, no existía una buena base legal cuando se trataba de planes más amplios. En este sentido se mencionaron dos excepciones, y en ambos casos involucraban a líderes de alto rango 90 .

Este importante avance en la jurisprudencia no se ocupa directamente del tema de plan o política de Estado como elemento de genocidio o crímenes de lesa humanidad. Sin embargo, la discusión aportada por la Sala de Apelaciones, el dictamen independiente del juez Bonomy, así como las doctrinas legales posteriores a la Segunda Guerra Mundial subrayaron la importancia del plan o política de Estado en el juicio de los líderes. 
El artículo 17(1)(d) del Estatuto de Roma de la Corte Penal Internacional establece que un caso puede ser declarado inadmisible cuando «no existe suficiente gravedad para justificar que la Corte siga con el proceso». El criterio de gravedad forma parte de una prueba de admisibilidad más amplia, y es la complementariedad su principal compañera. Muchos de los primeros comentaristas sobre admisibilidad abordaron el asunto como si fuera en esencia sinónimo de complementariedad y descuidaron en gran medida el tema de la gravedad. Una decisión temprana de la Sala de Cuestiones Preliminares de la Corte sugiere que el concepto de gravedad es mucho más importante de lo que muchos habían creído en un principio. Esta sala hizo notar que el umbral de gravedad era, «adicionalmente a la cuidadosa selección de los redactores de los crímenes incluidos en el artículo 6 a 8 del Estatuto, una selección basada en la gravedad y dirigida a restringir la competencia material de la Corte a 'los crímenes de mayor gravedad y preocupación internacional'» ${ }^{91}$. Como resultado de ello, «la conducta relevante debe presentar rasgos particulares que la conviertan en especialmente grave» ${ }^{92}$. Señaló que el umbral de gravedad pretendía asegurar que la Corte persiguiera casos solo contra «los líderes más importantes» en cualquier situación que se investigara ${ }^{93}$. También señaló que este factor estaba conformado por tres elementos. El primero es la posición que tuvo el acusado. El segundo es el papel desempeñado por esa persona «cuando las entidades estatales, organizaciones o grupos armados a los que pertenecen cometen crímenes sistemáticos a gran escala». El tercer elemento es el papel que tuvieron dichas organizaciones estatales, organizaciones o grupos armados en la comisión general de los crímenes. Según la sala, debido a la posición que dichas personas tienen, también son «quienes pueden prevenir o detener de manera más efectiva la comisión de dichos crímenes» ${ }^{94}$. Explicó que el umbral de gravedad representaba «una pieza clave que proporcionaron los legisladores para maximizar el efecto disuasorio de la Corte. Como resultado, la Sala debe concluir que cualquier efecto retributivo de las actividades de la Corte debe estar subordinado al propósito ulterior de la prevención.» ${ }^{95}$. La decisión incluyó la siguiente afirmación:

La Sala sostiene que deben tenerse en cuenta los siguientes dos rasgos. En primer lugar, la conducta que es objeto del caso debe ser sistemática (que haya una patrón de incidentes) o a gran escala. Si instancias aisladas de actividad criminal fueran suficientes, no habría necesidad de establecer un umbral adicional de gravedad más allá de la selección de crímenes condicionada por la gravedad (que se definen tanto

91 Fiscalía v. Lubanga (caso $\mathrm{N}^{\circ}$ ICC-01/04-01/06-8), Decisión sobre la aplicación de una orden judicial de arresto, 10 de febrero de 2006, párrafo 41.

92 lbid., párrafo 45.

93 lbid., párrafo 50.

94 lbid., párrafos 51-53.

95 Ibid., párrafo 48. 
por elementos contextuales como específicos) incluida en la competencia material de la Corte. En segundo lugar, al evaluar la gravedad de la conducta relevante, debe otorgarse la debida consideración a la alarma social que dicha conducta haya causado en la comunidad internacional ${ }^{96}$.

La Sala de Cuestiones Preliminares también justificó el énfasis en altos líderes, al hacer referencia a la práctica actual en los tribunales penales internacionales ad hoc de las Naciones Unidas. Resaltó la resolución 1534 del Consejo de Seguridad, la cual guía la estrategia de los tribunales ad hoc ${ }^{97}$. La resolución los exhorta a «concentrarse en los líderes con más alto rango de quienes se sospeche responsabilidad». También se hizo referencia a la norma 28(A) de las Normas de Procedimiento y Prueba del Tribunal Penal Internacional para la Antigua Yugoslavia, que autoriza a la agencia a bloquear la aprobación de las acusaciones que no cumplan con el estándar de los «altos líderes»; y a la norma 11 bis de las Normas de Procedimiento y Prueba, que establece «la gravedad de los crímenes procesados y el nivel de responsabilidad de los acusados» como el estándar que debe establecerse al transferir los casos de las cortes internacionales a las nacionales ${ }^{98}$. La Sala de Cuestiones Preliminares comparó los tribunales ad hoc, con su limitada jurisdicción en una situación de crisis, con la Corte Penal Internacional, que cuenta con una amplia competencia personal, temporal y territorial. «Desde el punto de vista de la Sala, es precisamente en este contexto donde uno reconoce el papel clave del umbral adicional de gravedad establecido en el artículo 17(1)(d) del Estatuto, al asegurar la efectividad de la Corte en el ejercicio de su función disuasoria y la maximización del efecto disuasorio de sus actividades», concluyó la Sala de Cuestiones Preliminares ${ }^{99}$.

Los expertos sobre el concepto de gravedad no consideran específicamente el plan o la política como un factor relevante. Sin embargo, el énfasis que otorgan al liderazgo confirma el rumbo que el Derecho penal internacional está tomando. Al evaluar la gravedad con la finalidad de seleccionar los casos, el elemento de plan o política de Estado puede probar ser de creciente utilidad. La existencia de un plan o política de Estado puede probar ser decisivo para distinguir los casos menos significativos de los que merecen ser conocidos por tribunales penales internacionales.

\section{CONCLUSIONES}

Los fallos de la Sala de Apelaciones del Tribunal Penal Internacional para la Antigua Yugoslavia afirman que, dentro del Derecho 
internacional consuetudinario, un plan o política de Estado no es un elemento del crimen de genocidio ni de los crímenes de lesa humanidad. Desafortunadamente, con relación tanto al genocidio como a los crímenes de lesa humanidad, el análisis de la Sala de Apelaciones no es particularmente profundo. En cada caso, la discusión es en extremo breve y se basa largamente en la lectura literal de los textos, además de representar una interpretación cuestionable de una cantidad relativamente pequeña de autores expertos en la materia. Las sentencias sugieren que estuvieron motivados más por políticas judiciales orientadas a resultados, teniendo en cuenta los detalles de los procesos en la antigua Yugoslavia, que por un análisis detallado de expertos legales, los orígenes de los conceptos, y el objeto y fin de las figuras de genocidio y crímenes de lesa humanidad.

La Sala de Apelaciones del Tribunal ha ejercido una gran influencia y ha aclarado muchos temas importantes dentro del Derecho penal internacional. Sin embargo, no es vinculante para sus sucesores, incluida la Corte Penal Internacional ${ }^{100}$. No solamente han de reconsiderarse las decisiones relacionadas con un plan o una política de Estado, sino que no pueden aplicarse de manera automática al Estatuto de Roma de la Corte Penal Internacional y a los Elementos del Crimen adoptados para su aplicación, pues sus disposiciones son diferentes. Tanto el estatuto como los elementos sugieren que el plan o política de Estado juega un papel en el contexto de los juicios por genocidio y crímenes de lesa humanidad.

Dos características recientes de la práctica que está desarrollándose dentro del Derecho penal internacional también argumentan en favor de un papel destacado del plan o política de Estado. Se ha establecido que la teoría de la empresa criminal conjunta se aplique a crímenes de atrocidad a gran escala. Los expertos anteriores, de los casos de la Segunda Guerra Mundial, han dejado claro que para ello hace falta que los líderes apliquen los planes o políticas, incluso si aquellos que los ejecutan son participantes inconscientes. Existirán dos componentes para establecer mens rea en estos casos: ¿existió un plan o política?, y, ¿el perpetrador tuvo conocimiento de la política y actuó con la intención de seguirla? Lo que se conoce como «umbral de gravedad» también tiene cierta relevancia. Debido a que los tribunales penales internacionales centran su atención en una cantidad limitada de criminales, están dirigiéndose a los líderes. En la práctica, hará falta identificar un plan o política y entonces procesar a los que tienen mayor responsabilidad por su implementación.

Probablemente la principal razón para fortalecer el requisito de plan o política sea articular de mejor manera la relación entre la responsabilidad del Estado y la responsabilidad penal individual. La sentencia de 
Nuremberg tuvo razón al insistir en que los crímenes son cometidos por individuos y por entidades abstractas. Sin embargo, los crímenes cometidos de manera aislada de las «entidades abstractas» tienen poco o ningún interés a nivel internacional. En efecto, la existencia de un plan o política de Estado puede ser el mejor criterio para distinguir entre crímenes individuales que corresponden a sistemas legales nacionales y crímenes internacionales, que contienen normas y principios especiales en cuanto a jurisdicción, inmunidad, limitaciones estatutarias y defensas.

Esto también arroja luz sobre el debate de mens rea, especialmente con respecto al genocidio. Durante varios años ha existido una preocupación por identificar la llamada «intención específica» o dolus specialis del genocidio. Este es un concepto proveniente de los sistemas legales nacionales, en los que se aplica a crímenes ordinarios. La migración de un sistema a otro no ha sido, sin embargo, fácil, sobre todo porque el genocidio requiere un sistema para su implementación. El procesamiento de quienes cometen genocidio sería mucho más claro si abandonáramos la pregunta sobre la intención específica y nos centráramos en el plan o la política. La persona que conoce la política y pretende seguirla debería ser condenada por genocidio. Cualquier otro puede ser juzgado por asesinato en los tribunales ordinarios.

Las preocupaciones que señalan que requerir un plan o política de Estado creará una laguna legal son infundadas. La mayoría de los llamados actores no estatales se encuentra más que adecuadamente desafiado por varios sistemas judiciales nacionales. Las necesidades de los procesos no son una ampliación de las definiciones de crímenes internacionales, sino un fortalecimiento de los mecanismos legales de cooperación internacional para facilitar que los delincuentes sean arrestados por crímenes «ordinarios». Es sobre todo cuando los perpetradores cometen actos atroces, precisamente por actuar en nombre de un Estado y según sus políticas, que requerimos que la justicia internacional intervenga. Insistir en que el plan o política es un elemento del crimen aclara la realidad de esta forma especial de criminalidad y facilita su distinción. 